\title{
Educationally Critical Aspects of the Concept of an Information System
}

\author{
Chris Cope \\ La Trobe University, Australia
}

c.cope@latrobe.edu.au

\begin{abstract}
An empirical study is reported which identified and compared a deep understanding of the concept of an information system (IS) with the various levels of understanding of a group of undergraduate IS students. The aim was to identify the educationally critical aspects of the deep understanding. The study was significant in that the educationally critical aspects are not known, yet have significant implications for IS education and practice. Without addressing the critical aspects in teaching and learning about IS the development of an appropriate deep understanding by students is unlikely. The production of entry-level IS practitioners without a deep understanding of the concept of an IS is logically likely to have adverse implications for IS development projects.
\end{abstract}

Keywords: Information system concepts, information system teaching, information system learning, phenomenographic research.

NOTE: A summary of the research reported in this article including Tables 2 and 3 and some of the section titled "Summary of critical aspects" has been previously published in the ACM copyrighted proceedings of the Fourth Australasian Computing Education Conference, Melbourne, December, 2000 (Cope, 2000b).

\section{Introduction}

Recent research into student learning has developed the notion that certain aspects of a concept are educationally critical to the development of a depth of understanding felt appropriate by the teacher for a particular learning situation. Without identifying the critical aspects in a research process and emphasising them in learning experiences, the development of an appropriate depth of understanding is, logically, highly unlikely (Booth, 1997; Cope, 2000a; Marton \& Booth, 1997).

A review of the IS education research literature revealed that an appropriate depth of understanding of the concept of an IS for new graduates has not been explicitly described and the educationally critical aspects of this understanding not researched. Indeed, the development of a deep understanding of the concept of an IS is not emphasised in IS undergraduate curricula, textbooks or teaching. Consequently, there is the possibility that IS graduates are

Material published as part of this journal, either on-line or in print, is copyrighted by the publisher of Informing Science. Permission to make digital or paper copy of part or all of these works for personal or classroom use is granted without fee provided that the copies are not made or distributed for profit or commercial advantage AND that copies 1) bear this notice in full and 2) give the full citation on the first page. It is permissible to abstract these works so long as credit is given. To copy in all other cases or to republish or to post on a server or to redistribute to lists requires specific permission and payment of a fee. Contact Editor@inform.nu to request redistribution permission. entering practice without an appropriate depth of understanding of the concept at the core of the discipline. This is a serious concern as an argument has been made for a logical link between the lack of emphasis on the concept of an IS in undergraduate curricula, an inadequate understanding of the concept of an IS in new graduates as prospective professionals, poor communication with clients during requirements gathering in practice, and the possible failure of information systems (Cope, 2000a; Cope \& Horan, 1998; Cope, Horan \& Garner, 1997; Weber, 1996).

Lack of knowledge about the educationally critical aspects of the concept of an IS would appear to be a significant problem for IS education and practice. The aim of this paper is to report an empirical study which sought to address this lack of knowledge.

\section{Theoretical Background}

The notion that a concept like an IS has educationally critical aspects has been developed in the work of Booth (1994, 1997), Cope (2000a), Marton (1998) and Marton and Booth $(1996,1997)$. Underlying the notion is a consistent finding of phenomenographic research into the different ways particular phenomena can be understood and the interpretation of these findings in terms of the analytical framework of a structure of awareness. 


\section{A Consistent Finding of Phenomenographic Studies}

Phenomenographic research approaches were designed in the early 1970s to qualitatively investigate the different ways that phenomena in the world can be perceived, conceptualised and understood (Marton, 1986). Phenomenographic studies take a second order research perspective. A first order perspective involves a researcher making statements about the world. A second order perspective involves a researcher making statements about other peoples' experiences of the world (Marton, 1981).

One of the consistent findings of phenomenographic studies is that a group of individuals will understand the same phenomenon in a limited number of distinctly different ways. Importantly the different understandings have been found to be related hierarchically based on logical inclusiveness and increased level of understanding. An example is needed to illustrate this finding. A study of variation in understanding of the nature of computer programming was conducted by Booth (1992). Three distinctly different levels of understanding were identified among a group of Swedish undergraduate computer science students. Computer programming was perceived variously as a computer oriented activity, a problem solving activity, and a product producing activity. The three levels of understanding formed a hierarchy based on logical inclusiveness. An understanding of computer programming as a product producing activity was found to include the notions that the product solved a problem and used a computer to do it. The product producing orientation was considered to be the deepest level of understanding identified and the level of understanding appropriate for the students.

\section{The Analytical Framework of a Structure of Awareness}

Recent attempts have been made to give the phenomenographic research process a stronger theoretical basis. To describe and compare different levels of understanding of the same phenomenon Marton and Booth (1997) and Cope (2000a) have used the analytical framework of a structure of awareness, developed from the field of consciousness described by Gurwisch (1964). Describing and analysing different levels of understanding in this way has provided new insights into the nature of the critical differences between levels of understanding and how a deep understanding can be attained. These insights are central to the study reported in this paper and need clarification. A description of a structure of awareness based on Booth $(1992,1997)$, Bowden and Marton (1999), Cope (2000a), Marton (1998) and Marton and Booth (1997) follows and Figure 1 is a diagrammatic interpretation.
Gurwitsch (1964) suggested that awareness is made up of three overlapping areas: the margin, the thematic field and the theme. When contemplating some phenomenon in the world at a particular time and in a particular context, an individual's awareness is likely to consist of aspects of the phenomenon triggered by the context. These aspects will be simultaneously present in awareness and are known collectively as the thematic field. The individual will also be aware in a less focused sense of other aspects of the world not considered to be related to the phenomenon, for instance, the noise of a car driving past. These non-related aspects of the world make up the margin of awareness. Out of all the aspects making up the thematic field, a number of related aspects of the phenomenon will emerge and become the focus of awareness. These related aspects are known as the theme of awareness.

A structure of awareness has also been described by Marton and Booth (1997) in terms of an internal and external horizon. The internal horizon consists of the aspects of the phenomenon simultaneously present in the theme of awareness and the relationships between these aspects. The external horizon consists of the thematic field and the margin, that is, all experiences that are part of awareness at a particular instant but which are not thematic. The external horizon as an area of awareness forms the context in which the theme sits. The boundary between the external and internal horizons delimits the phenomenon from its context.

An example of experiencing a deer in the woods is used by Marton and Booth (1997, p.87) to illustrate internal and external horizons:

Thus, the external horizon of coming on the deer in the woods extends from the immediate boundary of the experience - the dark forest against which the deer is discerned - through all other contexts in which related occurrences have been experienced (e.g. walks in the forest, deer in the zoo, nursery tales, reports of hunting incidents, etc.). The internal horizon comprises the deer itself, its parts, its stance, its structural presence.

Awareness, then, has a structure which can be described in terms of an internal and external horizon and the relationship between them. According to Marton and Booth (1997), the meaning given by an individual to a phenomenon, that is their level of understanding of the phenomenon, lies in the individual's structure of awareness when they contemplate the phenomenon. A level of understanding of a phenomenon, then, can be analyzed and described in terms of a structural aspect (the internal and external horizons of awareness) and a referential aspect (the meaning inherent in the structure). 


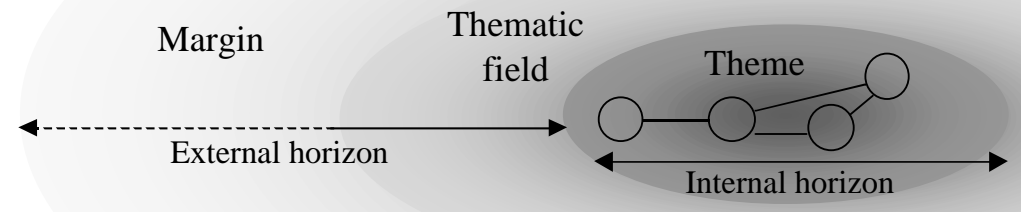

Figure 1: A structure of awareness (Cope, 2000a)

Significantly different levels of understanding of a phenomenon can be described and compared in terms of different structures of awareness. Differences can be with respect to the number of aspects of the phenomenon comprising the internal horizon, the nature of an aspect, the number and strength of the relationships between the aspects, and the nature of the boundary between the internal and external horizons. Deeper understandings of a phenomenon are likely to involve more aspects of the phenomenon in the internal horizon and/or a change in the nature of an aspect and/or more and better defined relationships between the aspects, and/or a change in the nature of the boundary between the internal and external horizons.

\section{The Notion of Critical Aspects of a Deep Understanding of a Phenomenon}

The notion of critical aspects of a deep understanding of a particular phenomenon lies in the consistent finding of a hierarchy of logically inclusive, distinctly different, increasingly deep levels of understanding of the same phenomenon. The aspects, relationships and boundaries of awareness in which the distinct differences lie are educationally critical aspects of a deep understanding of the phenomenon. In order to develop a deep understanding, logically, these critical aspects must be experienced in learning or real life situations. A teacher designing and implementing learning tasks which address the educationally critical aspects of a phenomenon is more likely to assist students to develop a deeper understanding.

\section{An Empirical Study of the Critical Aspects of a Deep Understanding of the Concept of an IS Appropriate for New Graduates}

An empirical study was conducted which aimed to improve student learning about the concept of an IS at the undergraduate level. Based on the theoretical background, four processes were required to identify educationally critical aspects of a depth of understanding of the concept of an IS appropriate for new graduates. First, the nature of an appropriate deep understanding was described from the literature. Secondly, the nature of less deep levels of understanding was identified in an empirical study of a group of undergraduate students. Thirdly the various levels of understanding were analysed to describe the critical differences between the levels. These critical differences were then collated to describe educationally critical aspects of the deep understanding of the concept of an IS. All descriptions and analysis were in terms of the framework of a structure of awareness.

\section{A Deep Understanding of the Concept of an IS Appropriate for New Graduates}

A number of descriptions of the general nature of an IS can be found in the published literature in the form of textbook definitions, journal articles and reports of task groups. An overview of the literature describes a dilemma, a vigorous debate as to whether an IS is a technical system, consisting only of IT artefacts, or a social system consisting of people performing meaningful organisational activity supported by embedded IT. Supporters of the technical view include Alter (1999), Clarke (1992) and 
Wand and Weber (1995). Support for a social view can be found in Beynon-Davies (1998); Callaos and Callaos, (2002); Land (1992); Winter, Brown and Checkland (1995); the report of the IFIP WG 8.1 Task Group FRISCO (Framework of Information System Concepts) (Falkenberg et al., 1996); and the many publications of the IFIP WG 8.2 task group.

An analysis of the arguments (Cope, Horan \& Garner, 1997; Cope, 2000a) suggests that new IS graduates, in order to perform effectively in practice, need to understand an IS as a social system of people performing purposeful organisational activity, supported by embedded IT. The internal horizon of this understanding consists of people and IT. The people make decisions which lead to the purposeful activity. The decision making processes are based on meaning which has been sought and attributed by the people to:

1. the output of computerised data manipulation systems and/or

2. data from external sources, for instance census data.

3. informal data flow, for instance other people either inside or outside the organisation, and/or

4. direct observation of relevant aspects of the real world.

The IT embedded in the system provides support to the people by enhancing any of the storage, maintenance, selection, organisation, presentation and communication of all data required for effective decision making. The IT may be in the form of computerised data manipulation systems supporting designed data flow, communication devices supporting informal data flow and access to external data, and technology assisting observation of the real world.. A computerised data manipulation system needs to be experienced as related user interface, control, processing and database sub-systems. Data flows between the various subsystems under the control of the control sub-system.

The interaction between the IT and the people lies in a system served/system serving relationship and in the process of attribution of meaning prior to decision making. The IT serves the organisational activity through supporting effective decision making. The process of attribution of meaning according to Checkland and Holwell (1995, 1998 ) is a human activity that involves taking organised and unorganised data from the formal and/or informal channels and/or direct observation and placing the data in the context of the bigger organisational picture to form information.
Contemporary information systems involve an extended interaction between IT and people that has not yet generally permeated the literature. In situations where meaning attribution and decision making can be described algorithmically and emulated by software, the IT can support and, in some cases like process control, make decisions.

The external horizon of this deep understanding of the concept of an IS refers to the scope of an IS. Modern information systems can span organisational functions, organisations and continents.

The conclusion that an IS needs to be understood by new graduates as a social system supported by embedded IT is based on:

1. A consideration of the literature which reports the failure of a significant proportion of IS development projects (for example KPMG, 1995) and the literature which reports the focus of current IS developers on the technical aspects of an IS (Davenport, Eccles and Prusak, 1992; Mumford, 1996; Sahraoui, 1998).

2. The likelihood of a technical-only view of an IS leading to a lack of significance being attached to the way people involved with the IS attribute meaning to the system's data and information. To improve the chances of success any IS development project needs to understand how the people in an organisation attribute meaning and how this meaning drives action. From Land's (1992) perspective this requires an IS developer to be aware that people need information delivered differently depending on their prior knowledge and cognitive style and environmental and situational factors.

Certain aspects of the concept of an IS will be critical to the development of this deep understanding. These aspects will be apparent when considering critical differences between shallower and deeper levels of understanding. The next section describes the method and results of a phenomenographic study of the levels of understanding of the concept of an IS among a group of undergraduate IS students. The students were presumed to hold shallower levels of understanding in comparison to the deep understanding just described.

\section{The Levels of Understanding of the Concept of an IS Among a Group of Undergraduate Students}

\section{Method}

A phenomenographic study was undertaken to give insight into the different levels of understanding of the concept of an IS of students learning about IS for a year during the 
Bachelor of Computing at La Trobe University, Bendigo, Australia. The students involved were volunteers enrolled in the subjects Information Systems

http://ironbark.bendigo.latrobe.edu.au/subjects/int10is/IN TTOISHomePage.htm and IS Development

(http://1ronbark.bendigo.latrobe.edu.au/subjects/int20isd).

Following accepted phenomenographic research techniques data was collected using in-depth interviews and short-answer questionnaires. Twenty-three students were interviewed at the beginning of the year of study about IS and 15 of the same students again at the end of the year. Short-answer questionnaires were completed by all students present in the lectures at the beginning (81 students), middle (62 students) and end (59 students) of the year of study.

The guide questions for the interviews and the short answer questions on the questionnaires

(http://ironbark.bendigo.latrobe.edu.au/4taff/cope/question s.pdf) were designed to encourage students to reflect on their understanding of the concept of an IS. After a student responded to a guide question the response was probed where necessary by asking for further explanation, clarification of terms the student had used or a different view on the question. To avoid leading the student, only terms already introduced by the student were used. During the questioning the interviewer's focus was on the student's underlying views of what was being talked about, probing for the relevant external and internal horizons and the meaning the student ascribed to an IS. Thus, analysis in terms of the analytical framework of a structure of awareness was occurring as part of data collection.

For further analysis, the interviews and questionnaire responses were transcribed. The transcripts were then treated as a large pool of decontextualised quotes about the concept of an IS. Quotes varied in size from the response to a single question to the responses to a number of sequential questions. The pool of quotes was analysed using a phenomenographic technique. The aim of the analysis was to describe, in terms of a structure of awareness, the distinctly different views of an IS underlying the pool of quotes as a whole. To achieve this aim the researcher initially considered each quote separately. The questions asked of each quote were: what aspects of an IS make up the internal horizon; what is the nature (value in the possible range of values) of each aspect; how are the aspects related; and what is the nature of the boundary between the internal and external horizons (how is an IS delimited in its organisational context)?

The quotes were then grouped on the basis of contributing to a distinctly different structure of awareness. In an iterative process quotes and the groups of quotes were revisited many times seeking distinct differences in either the internal horizons or external horizons of the relevant structures of awareness. The meaning intimated by, and relationships between the different structures of awareness were considered. At the completion of the analysis phase, underlying each group of quotes was a distinctly different structure of awareness. In clarifying the meaning associated with a structure of awareness, a distinctly different level of understanding of the concept of an IS was described. The different levels of understanding were then given a title, described in detail in terms of a structure of awareness, illustrated with quotes from the pool, and presented in a hierarchy of inclusiveness and depth of understanding.

The validity of the phenomenographic study is claimed through the full and open description of the method and results. Reliability was assessed through a test of interjudge communicability of the hierarchy of different levels of understanding of an IS (Cope, 2000a; Sandberg, 1994, 1997). Three other researchers were provided with a description of the hierarchy and 10 quotes from the interview transcripts. The researchers were asked to classify the level of understanding of the concept of an IS underlying each quote against the hierarchy and provide a reason for the classification. Once the classification had occurred consultation took place where practical with the other researchers over any differences. Table 1 presents the results of the test of interjudge communicability of the different levels of understanding of the concept of an IS. On the basis of the figures in Table 1 acceptable communicability is claimed. The other researchers could see the different levels of understanding in the data.

\begin{tabular}{|c|c|c|c|}
\cline { 2 - 4 } \multicolumn{1}{c|}{} & Researcher 1 & Researcher 2 & Researcher 3 \\
\hline $\begin{array}{c}\text { Percentage } \\
\text { agreement before } \\
\text { consultation }\end{array}$ & $80 \%$ & $90 \%$ & $60 \%$ \\
\hline $\begin{array}{c}\text { Percentage } \\
\text { agreement after } \\
\text { consultation }\end{array}$ & $100 \%$ & $90 \%$ & $80 \%$ \\
\hline
\end{tabular}

\section{Table 1: Interjudge measure of communicability of levels of understanding of the concept of an IS (10 quotes)}

\section{Results}

The outcome of the phenomenographic analysis of the interview transcripts and questionnaires was a hierarchy of 6 qualitatively different levels of understanding of the concept of an IS (Table 2). Each level of understanding is described in terms of a structure of awareness. The hierarchy is based on logical inclusiveness and increased depth 
of understanding. Levels of understanding higher in the hierarchy are inclusive of and represent a deeper understanding of the concept of an IS than those lower in the hierarchy. Levels of understanding higher in the hierarchy have more related aspects of an IS as part of the internal horizon and an external horizon which delimits an IS as a much broader entity within an organisation. Levels of understanding 1 through 4 represent strictly technical views of an IS. Levels of understanding 5 and 6 incorporate people in the IS, one aspect of an IS as a social system. Illustrative quotes from the data for each level of understanding are available -

http://ironbark.bendigo.latrobe.edu.au/staff/cope/quotes.pdf.

\section{Comparison of the Undergraduate Students' Levels of Understanding with the Deep Understanding}

The review of the appropriate IS literature and the phenomenographic study reported in the previous sections identified seven distinctly different levels of understanding of the concept of an IS. These understandings were analysed and compared to identify critical differences. The critical differences were then collated to describe the critical aspects. All analysis and comparisons were in terms of the framework of a structure of awareness.

The various aspects of an IS in which critical differences were identified are illustrated in Table 3 . The rows in the table represent the various levels of understanding of the concept of an IS identified in the study. The columns in the table represent aspects of the concept of an IS in which critical differences in understanding were identified. Dark grey shading in a cell indicates a clearly understood aspect of an IS. Light grey shading represents an awareness of the aspect but an incomplete understanding of the nature of the aspect. Text in a cell describes the nature of the aspect. The dark lines across one or more rows in a column represent the location of a critical difference in the aspect of an IS in the column.

From the perspective of a structure of awareness, a critical difference between the levels of understanding of an IS implied one of four situations. First, the nature of the understanding of an aspect of an IS changes in a significant way towards the value associated with the deep understanding. For instance all levels of understanding of

an IS incorporate a database as an aspect (aspect 2 in Table 3 ). In the lower levels of understanding the database is conceptualised as being static, that is the data does not change in the short term. Deeper levels of understanding of an IS incorporate a view of a database as a dynamic entity, that is the data is constantly changing. Secondly, an aspect of an IS that is an integral aspect of the deep understanding is not part of the shallower levels of understanding. For instance the interview transcripts and questionnaires did not demonstrate any awareness on the 72 demonstrate any awareness on the students' part of the user interface or control sub-systems of an IS (aspect 5). Thirdly, new or stronger relationships exist between aspects of the IS. For instance, a vital aspect of the deep understanding is a recognition of the strong relationships between the user interface, control, processing and database aspects of an IS (aspect 6). This relationship is not part of the students' levels of understanding. Fourthly, the nature of the boundary between the internal and external horizons is different. For instance, the deep understanding views an IS as incorporating multiple organisational functions (aspect 9). Levels 1 through 5 view an IS as pertaining to a single organisational function.

Logical arguments can be put for the educationally critical nature of the differences in understanding that were identified (Cope, 2000a). The arguments are generally based on the need for an aspect of an IS, or a relationship between aspects of an IS, or the extended scope of an IS in an organisation to be recognised if information systems are to be designed, developed and operated effectively. For instance, the user interface was not recognised as the physical link between the technical and social aspects of an IS in the various student levels of understanding (aspect 13). But the people involved in the IS relate to the information technology through a user interface. The user interface, in turn, is one of the technical aspects of the IS. The design of the user interface impacts heavily on the attribution of meaning aspect of the IS. The ability of people to attribute meaning to organised data in a way designed by the IS developer to facilitate effective decision making is influenced by the design of the user interface. If data, for instance, is presented via the user interface in a way which clashes, as Land (1992) suggests, with the users' cognitive style, prior knowledge, language and information channel preferences, there is the possibility that meaning will not be attributed in a way which will lead to effective decision making. A lack of recognition of the user interface as the physical link between the social and technical aspects of an IS and a critical component of the process of attribution of meaning is a critical difference between the students' levels of understanding and the deep understanding.

Aspects of an IS in which there were critical differences were considered as critical aspects of a deep understanding of the concept of an IS. The critical aspects are summarised in the next section. 


\begin{tabular}{|c|c|c|c|}
\hline \multirow{2}{*}{ Level } & \multirow{2}{*}{$\begin{array}{c}\text { Referential aspect } \\
\text { Meaning } \\
\end{array}$} & \multicolumn{2}{|c|}{ Structural aspect } \\
\hline & & Internal horizon & External horizon \\
\hline 6 & $\begin{array}{l}\text { A number of communicating information } \\
\text { systems within a single organisation }\end{array}$ & $\begin{array}{l}\text { All people, computer hardware, data and information } \\
\text { related processes associated with communicating in- } \\
\text { formation systems within a single organisation. The } \\
\text { relationships between and within the different aspects } \\
\text { of the IS are not well understood. }\end{array}$ & $\begin{array}{l}\text { Delimits an IS to a number of communicating in- } \\
\text { formation systems of the type experienced in } \\
\text { level } 5 \text { within a single organisation. }\end{array}$ \\
\hline 5 & $\begin{array}{l}\text { A computerised data manipulation system } \\
\text { and all the people and the data-related pro- } \\
\text { cedures they perform to support a single } \\
\text { organisational function. }\end{array}$ & $\begin{array}{l}\text { Data collection procedures, multiple data inputs, mul- } \\
\text { tiple processes, multiple information outputs, informa- } \\
\text { tion dissemination procedures. All people involved } \\
\text { with generating or collecting input, input of data, gen- } \\
\text { eration of output or dissemination of output. All people } \\
\text { who receive and use information from the system. } \\
\text { Computer hardware and software. }\end{array}$ & $\begin{array}{l}\text { Delimits an IS as in level } 4 \text { but includes data col- } \\
\text { lection and information dissemination procedures } \\
\text { as well as any people who generate input, receive } \\
\text { output and who are involved in data collection, } \\
\text { output dissemination and use of information per- } \\
\text { taining to single organisational function. }\end{array}$ \\
\hline 4 & $\begin{array}{l}\text { A computerised data manipulation system } \\
\text { supporting many people within a single or- } \\
\text { ganisational function. }\end{array}$ & $\begin{array}{l}\text { Multiple data inputs, multiple processes, multiple in- } \\
\text { formation outputs and a dynamic database. Computer } \\
\text { hardware and software. Understanding of the data ma- } \\
\text { nipulation processes remains poor. There is some un- } \\
\text { derstanding that the database is structured rather than a } \\
\text { mass of undifferentiated data. }\end{array}$ & $\begin{array}{l}\text { Delimits an IS to the processes which maintain } \\
\text { and manipulate data to support the many people } \\
\text { associated with a single organisational function } \\
\text { but with different data and information require- } \\
\text { ments within that function. The people are not } \\
\text { considered to be nart of the IS. }\end{array}$ \\
\hline 3 & $\begin{array}{l}\text { A data manipulation system supporting an } \\
\text { individual within a single organisational } \\
\text { function. }\end{array}$ & $\begin{array}{l}\text { Initial input of data to a database, input of data to keep } \\
\text { the database current, a dynamic database, requests for } \\
\text { information, processing of the relevant data to form the } \\
\text { required information and the output of information. } \\
\text { Sometimes computer hardware and software. Under- } \\
\text { standing of the nature of the processing, the structure } \\
\text { of the database and the relationship between them is } \\
\text { weak. }\end{array}$ & $\begin{array}{l}\text { Delimits an IS to the processes which maintain } \\
\text { and manipulate data to support an individual in- } \\
\text { volved with a single organisational function. The } \\
\text { person is not considered to be part of the IS. }\end{array}$ \\
\hline 2 & A simple information retrieval system. & $\begin{array}{l}\text { A database, a query on the database, a process which } \\
\text { extracts the relevant data from the database and an } \\
\text { output. The relationships between the different aspects } \\
\text { of the IS and the structure within the aspects are poorly } \\
\text { discerned. }\end{array}$ & $\begin{array}{l}\text { Delimits an IS to a single simple query and a } \\
\text { process external to an individual which manipu- } \\
\text { lates data from a simple, static database to pro- } \\
\text { duce information. The person is not considered to } \\
\text { be part of the IS. }\end{array}$ \\
\hline 1 & $\begin{array}{l}\text { A personal search of a static information } \\
\text { source }\end{array}$ & A static source of information and a personal search & $\begin{array}{l}\text { Delimits an IS to a personal search of a source of } \\
\text { static information. The person is not considered } \\
\text { to be part of the IS but the process of searching is. }\end{array}$ \\
\hline
\end{tabular}

Table 2: Levels of understanding of the concept of an IS from the student data (described in terms of a structure of awareness) (Cope, 2000b) 


\begin{tabular}{|c|c|c|c|c|c|c|c|c|c|c|c|c|c|}
\hline \multirow[b]{3}{*}{$\begin{array}{l}\text { Level of un- } \\
\text { derstanding }\end{array}$} & \multicolumn{7}{|c|}{ Technical aspects } & \multicolumn{4}{|c|}{ Social aspects } & \multicolumn{2}{|c|}{$\begin{array}{c}\text { Relationship between technical } \\
\text { and social aspects }\end{array}$} \\
\hline & 1 & 2 & 3 & 4 & 5 & 6 & 7 & 8 & 9 & 10 & 11 & 12 & 13 \\
\hline & $\begin{array}{l}\text { Nature of } \\
\text { queries sup- } \\
\text { ported }\end{array}$ & $\begin{array}{l}\text { Nature of } \\
\text { database }\end{array}$ & $\begin{array}{l}\text { Who can } \\
\text { instigate } \\
\text { changes to } \\
\text { data? }\end{array}$ & $\begin{array}{l}\text { Location and } \\
\text { nature of proc- } \\
\text { esses }\end{array}$ & $\begin{array}{l}\text { User interface } \\
\text { and control } \\
\text { subsystems. }\end{array}$ & $\begin{array}{l}\text { Relationship } \\
\text { between user } \\
\text { interface, con- } \\
\text { trol, processing } \\
\text { and database } \\
\text { subsystems. }\end{array}$ & $\begin{array}{c}\text { No. of } \\
\text { users } \\
\text { served by } \\
\text { IS. }\end{array}$ & $\begin{array}{c}\text { People } \\
\text { other than } \\
\text { the direct } \\
\text { operator } \\
\text { as part of } \\
\text { the IS? }\end{array}$ & $\begin{array}{l}\text { Number of } \\
\text { organisational } \\
\text { functions in- } \\
\text { volved }\end{array}$ & $\begin{array}{c}\text { Attribution of } \\
\text { meaning as a } \\
\text { human activ- } \\
\text { ity }\end{array}$ & $\begin{array}{c}\text { Informal in- } \\
\text { formation } \\
\text { flow }\end{array}$ & $\begin{array}{c}\text { System served/ } \\
\text { system serving } \\
\text { relation between } \\
\text { social and tech- } \\
\text { nical aspects }\end{array}$ & $\begin{array}{l}\text { User interface } \\
\text { as physical } \\
\text { link between } \\
\text { social and } \\
\text { technical } \\
\text { aspects }\end{array}$ \\
\hline Deep & Complex & Dynamic & $\begin{array}{l}\text { Multiple } \\
\text { users }\end{array}$ & $\begin{array}{c}\text { Within and be- } \\
\text { yond the com- } \\
\text { puter. } \\
\text { Computerised and } \\
\text { manual. }\end{array}$ & $\begin{array}{c}\text { Accepts and } \\
\text { validates } \\
\text { input. Directs } \\
\text { processing. } \\
\text { Displays } \\
\text { output. }\end{array}$ & $\begin{array}{l}\text { Ability to con- } \\
\text { ceptualise flow } \\
\text { of control and } \\
\text { data between } \\
\text { subsystems. }\end{array}$ & Multiple & Yes & More than one. & $\begin{array}{c}\text { Only people } \\
\text { can interpret } \\
\text { input to and } \\
\text { output from } \\
\text { the IT }\end{array}$ & \begin{tabular}{|c|} 
An un- \\
designed \\
source of \\
information \\
important in \\
decision mak- \\
ing \\
\end{tabular} & $\begin{array}{l}\text { IT should sup- } \\
\text { port, rather than } \\
\text { dictate the na- } \\
\text { ture of, organ- } \\
\text { isational activity }\end{array}$ & $\begin{array}{l}\text { User interface } \\
\text { design influ- } \\
\text { ences how } \\
\text { meaning is } \\
\text { attributed }\end{array}$ \\
\hline 6 & Complex & Dynamic & $\begin{array}{l}\text { Multiple } \\
\text { users }\end{array}$ & $\begin{array}{c}\text { Within and be- } \\
\text { yond the com- } \\
\text { puter. } \\
\text { Computerised and } \\
\text { manual. }\end{array}$ & & & Multiple & Yes & More than one. & Use of output & $\begin{array}{c}\text { Some formal } \\
\text { interaction } \\
\text { between peo- } \\
\text { ple }\end{array}$ & & \\
\hline 5 & Complex & Dynamic & $\begin{array}{l}\text { Multiple } \\
\text { users }\end{array}$ & $\begin{array}{c}\text { Within and be- } \\
\text { yond the com- } \\
\text { puter. } \\
\text { Computerised and } \\
\text { manual. }\end{array}$ & & & Multiple & Yes & One & Use of output & $\begin{array}{c}\text { Some formal } \\
\text { interaction } \\
\text { between peo- } \\
\text { ple }\end{array}$ & & \\
\hline 4 & Complex & Dynamic & $\begin{array}{l}\text { Multiple } \\
\text { users }\end{array}$ & $\begin{array}{c}\text { Within the com- } \\
\text { puter. } \\
\text { Computerised. }\end{array}$ & & & Multiple & & One & & & & \\
\hline 3 & Complex & Dynamic & User & $\begin{array}{l}\text { External to the } \\
\text { person. } \\
\text { May be computer- } \\
\text { ised or manual. }\end{array}$ & & & One & & One & & & & \\
\hline 2 & Complex & Static & Not user & $\begin{array}{l}\text { External to the } \\
\text { person. } \\
\text { May be computer- } \\
\text { ised or manual. }\end{array}$ & & & One & & One & & & & \\
\hline 1 & Simple & Static & Not user & $\begin{array}{l}\text { External to the } \\
\text { person. } \\
\text { Manual. }\end{array}$ & & & One & & One & & & & \\
\hline
\end{tabular}

Table 3: Comparison of the various levels of understanding of the concept of an IS (Cope, 2000b) 


\section{Summary of Critical Aspects}

There were found to be critical aspects of the technical and social parts of an IS and the relationship between the social and technical aspects. Without addressing all of these issues in learning experiences, students are unlikely to develop the depth of understanding appropriate for new graduates.

\section{Critical technical aspects}

1. An awareness of the nature of a dynamic database and the processes necessary to accurately and efficiently store and maintain data in a database and respond to complex queries and various ways of presenting data.

2. An ability to simultaneously be aware of the control, user interface, processing and database sub-systems of an IS including the detail of each sub-system and the relationships between them. It is critical that new graduates are able to conceptualise the related processes which accept an action from a user interface, validate the action and respond to the action, for instance changing or manipulating the relevant data in the database and presenting appropriate feedback via the user interface.

3. An awareness of the IT aspects of an IS as a multiuser environment with the different people possibly geographically separated. Conceptualising the impact of multiple, separated users on the related user interface, control, processing and database sub-systems is a vital part of this awareness.

\section{Critical social aspects}

A deep understanding of the concept of an IS views an IS as extending beyond the information technology to incorporate the people in the organisational function(s) and the procedures the people perform. Two social aspects of an IS were found to be critical to a deep understanding. Specifically these were:

1. An awareness of the process of attribution of meaning as a human activity and the need to incorporate this process and people undertaking this process in the IS.

2. Experiencing informal information flow between the people in an organisation as part of an IS.

\section{Critical aspects of the relationship between the social and technical aspects of an IS}

A deep understanding of the concept of an IS incorporates an awareness that the social and technical aspects of an IS are related. Critical aspects of this relationship include:
1. An awareness that the essence of this relationship lies in the system served/system serving principle of Winter, Brown and Checkland (1995). The IT is embedded in the system of people and machines performing organisational activity and serves the system through supporting and enhancing formal and informal information flow and decision making. For this serving function to be achieved, the importance must be recognised of understanding the organisational activity before designing the supporting IT system.

2. A realisation that the user interface of the IT aspects of an IS is the physical link between the technical and social aspects and vital to appropriate attribution of meaning and, hence, effective decision making.

\section{Implications for Teaching about the Concept of an IS}

A problem alluded to earlier in the paper was the lack of emphasis given to the development of a deep understanding of the concept of an IS in current undergraduate IS curricula. This lack of emphasis directly contradicts the finding of multiple educationally critical aspects of the concept of an IS. An IS is a complex, multi-facetted concept. The findings of the study reported here and personal experience of IS undergraduate model curricula and curricula taught around the world suggest that it is highly unlikely that students are graduating with a depth of understanding adequate for effective practice. So how can IS educators provide more emphasis on the concept of an IS in a curriculum already crowded with content?

Logically, the aspects of the concept of an IS which need to be emphasised and which will cause the minimum of change to the content of the curricula are the educationally critical aspects identified in the study. Based on the theoretical framework, educationally critical aspects are the vital aspects which must be addressed in the curriculum if the development of an adequate depth of understanding is to occur. Learning tasks need to be designed and implemented which address the educational critical aspects of the concept of an IS.

Claims are likely that specific implementations of IS curricula do emphasise a number of the critical aspects. For example database theory and practice are often taught as a separate course within an IS curriculum. It is the encouragement of the development in students of the relationships between the various aspects of an IS that is likely to lead to deeper understanding. Studies about database need to be linked to study about user interface design, for example. Consequently there needs to be cooperation across courses. 
Table 3 identifies a path of curriculum development toward a deep understanding. The path involves a movement from the lower left to the upper right in the table. Curriculum development involves moving the level of understanding of the concept of an IS up the hierarchy through sequentially and in some cases simultaneously addressing the critical differences between the levels of understanding. A deepening of understanding can involve recognising new aspects of an IS, and/or understanding aspects in a more desirable way, and/or recognising new or different relationships between aspects, and/or recognising the extent of an IS in its organisational context.

The proposed curriculum development path involves emphasising the IT aspects of an IS before the social aspects. The justification for this curriculum order lies in the Structure of Observed Learning Outcomes (SOLO) taxonomy, described by Biggs and Collis (1982, 1989), and Bloom's taxonomy of competency levels (Bloom, 1956). Both of these well-respected scales of learning objectives and outcomes highlight the importance of emphasising more concrete learning experiences before more abstract ones.

Young students early in their studies about IS are likely to be more comfortable with the hands on, technical aspects of an IS rather than the more abstract social aspects which are likely to be beyond their life experiences. Whilst the social aspects of an IS need to be introduced to students early in the curriculum, emphasis needs to come later when students have more life experience, more refined learning approaches and smaller student numbers are more conducive to the experiential learning activities required to effectively address the social aspects of an IS.

Emphasis on the development of a deep understanding of the concept of an IS needs to be made explicit to students. As a consequence and progressively through the curriculum, learning tasks need to thematise, for the students and the teacher, the students' developing understanding of the concept of an IS. Learning tasks need to encourage students to reflect on their level of understanding. The teaching needs to provide perspectives on aspects and relationships of an IS that are not part of the students' understanding. Students need to be encouraged to reflect on the dif-

ferent perspectives on aspects of an IS, seeking the meaning in each perspective and interrelating the meanings to deepen understanding.

A valuable tool for focussing students' attention on their levels of understanding of the concept of an IS is the rich picture. Rich pictures are an IS development documentation tool designed by Checkland (1981) as part of his soft systems philosophy. Rich pictures are used to understand problem domains in organisational contexts. The pictures portray relevant aspects of an organisational context as icons or labels. Relationships between aspects of the con- texts are recorded with arrows and the relationships are named.

A rich picture, in effect, is a reflection of an individual's structure of awareness of the phenomenon the picture portrays. As such a student's rich picture of an IS reflects the student's level of understanding of the concept of an IS (Figure 2). Each aspect of an IS that is part of the student's internal horizon of awareness is represented by an icon on the rich picture. The icon or label chosen is a reflection of the student's understanding of the nature of the aspect of an IS. The named relationships between icons give insight into the relationships between aspects of an IS that the student recognises. The extent of the rich picture is a reflection of the student's external horizon of their level of understanding of an IS. A student's rich picture not only informs the student and teacher about the student's level of understanding, drawing of the rich picture forces the student to think about appropriate icons and the existence and nature of relationships between icons. A rich picture, therefore, is also a tool for deepening an understanding.

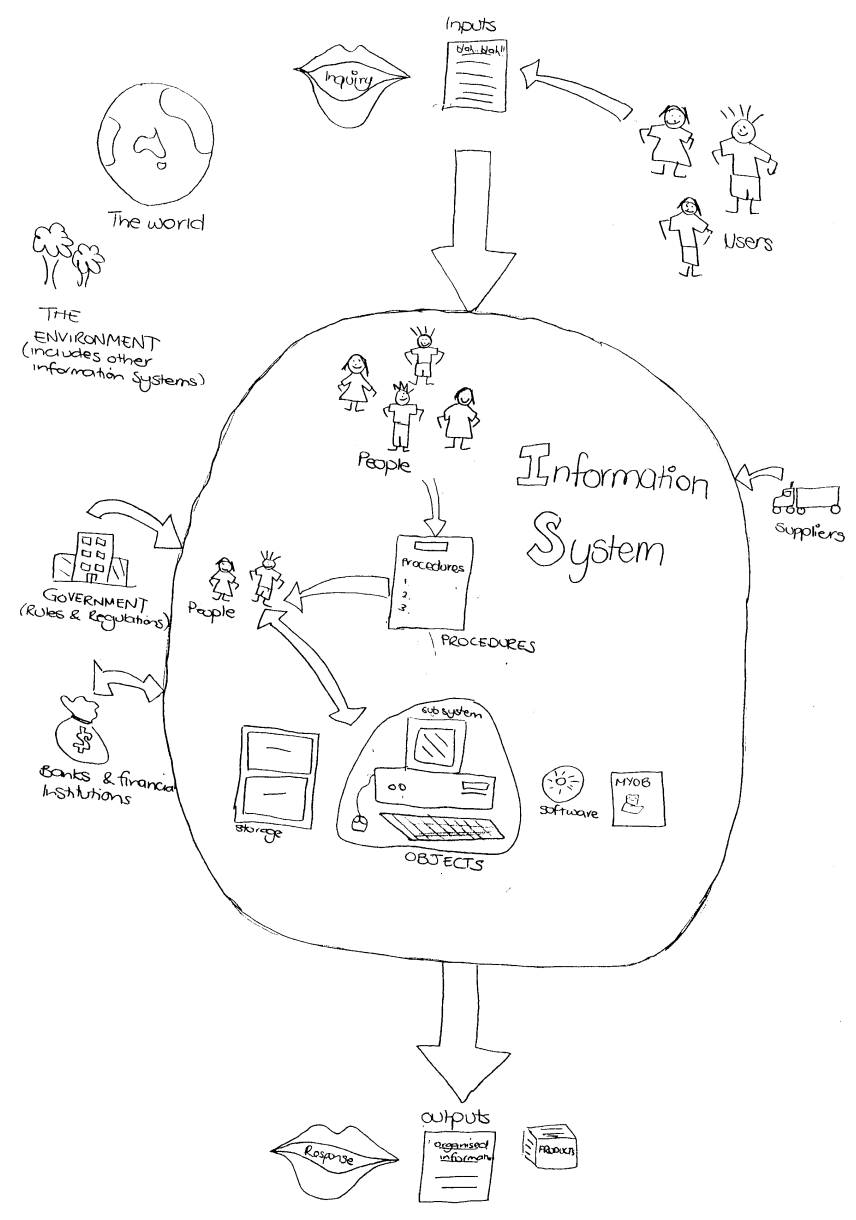

Figure 2: Student's rich picture of an IS 


\section{Conclusion}

The educationally critical aspects of the concept of an IS identified in this paper represent an important contribution to the literature. It is hoped that the contribution can lead to improvements in teaching and learning about IS resulting in more informed graduates.

The research reported needs to be a stimulus for more attempts to further understanding of the nature and critical aspects of the concept of an IS. The context of the empirical study was limited. Students' levels of understanding were investigated in two IS subjects in the Bachelor of Computing at La Trobe University, Bendigo, Australia. It is likely that only some of the possible variation in levels of understanding of the concept of an IS was identified. Hence there is no guarantee that all of the educationally aspects became evident. Similar research would be of value investigating the levels of understanding of students who had been studying about the concept of an IS in other countries, for a longer time, at different educational levels and through different methods of instruction.

The claim made in the paper that learning tasks which address the critical aspects of the concept of an IS are more likely to result in the development of a deep understanding is logically grounded. Empirical support for the claim is needed. Research is warranted which evaluates the impact of learning tasks designed to address the critical aspects. The hierarchy of levels of understanding of the concept of an IS described in the empirical study forms a measuring instrument which could be used in an evaluation.

\section{References}

Alter, S. (1999). A general, yet useful theory of information systems. Communications of the Association for Information Systems, [On-line journal] 1 , article 13. Available: http://ca1s.1sworld.org/contents.asp

Biggs, J. B., \& Collis, K. F. (1982). Evaluating the quality of learning: The SOLO taxonomy. New York: Academic Press.

Biggs, J. B., \& Collis, K. F. (1989). Toward a model of school-based curriculum development and assessment: Using the SOLO Taxonomy. Australian Journal of Education, 33, 149-161.

Beynon-Davies, P. (1998). Information systems development $\left(3^{\text {rd }}\right.$ ed.). London: MacMillan Press.

Bloom, B.S. (1956). The taxonomy of educational objectives: Classification of educational goals, handbook I: The cognitive domain. New York: McKay Press.

Booth, S.J. (1992). Learning to program: A phenomenographic perspective. (Göteborg Studies in Educational Sciences, 89). Göteborg: Acta Universitatis Gothoburgensis.
Booth, S.J. (1994). On phenomenography, learning and teaching, In R. Ballantyne \& C. Bruce (Eds.), Proceedings of Phenomenography, Philosophy and Practice (pp.3-6). Brisbane, Queensland: QUT Publications and Printing.

Booth, S.J. (1997). On phenomenography, learning and teaching. Higher Education Research and Development, 16 (2), 135-157.

Bowden, J.A. \& Marton, F. (1999). The University of Learning: Beyond quality and competence in higher education. London: Kogan Page.

Callaos, N. \& Callaos, B. (2002). Towards a systematic notion of information: Practical consequences. Informing Science, 5, (1), $1-11$.

Checkland, P. (1981). Systems thinking, Systems practice. Chichester, UK: Wiley.

Checkland, P., \& Holwell, S. (1995). Information systems: The big idea. Systemists, 17 (1), 7-13.

Checkland, P., \& Holwell, S. (1998). Information, systems and information systems - making sense of the field. England: Wiley.

Clarke, R. (1992). Extra-organisational systems: A challenge to the software engineering paradigm. Presented at the IFIP World Congress, Madrid, September. [On-line] Available: http://www.anu.edu.au/people/Roger.Clarke/SOS/PaperExtraOr gSys.html

Cope, C.J. (2000a). Educationally critical aspects of the experience of learning about the concept of an information system. Unpublished $\mathrm{PhD}$ thesis [On-line]. Available: ironbark.bendigo.latrobe.edu.au/staff/cope/cope-thesis.pdf

Cope, C.J. (2000b). Educationally critical aspects of a deep understanding of the concept of an information system. Proceedings of the Fourth Australasian Computing Education Conference, (pp. 48-55), New York: ACM.

Cope, C.J., \& Horan, P. (1998). Towards an understanding of teaching and learning about information systems. The Proceedings of the Third Australian Conference on Computer Science Education (pp. 188-197), New York: ACM.

Cope C.J., Horan, P., \&. Garner, M. (1997). Conceptions of an information system and their use in teaching about IS. Journal of Informing Science, 1 (1), 7-19.

Davenport, T.H., Eccles, R.G., \& Prusak, L. (1992). Information politics. Sloan Management Review, 34 (1), 53-65.

Falkenberg, E.D., Hesse, W., Lindgreen, P., Nilsson, B.E., Han Oei, J.L., Rolland, C., Stamper, R.K., Van Assche, F.J.M., VerrijnStuart, A.A., \& Voss, K. (1996). A Framework of Information Systems Concepts. Report of the IFIP WG 8.1 Task Group FRISCO.

Gurwitsch, A. (1964). The field of consciousness. Pittsburgh: Duquense University Press. 
KPMG. (1999). Runaway projects - cause and effects, Software World (UK), 26 (3), 3-5.

Land, F. F. (1992). The information systems domain. In R. Galliers (Ed.), Information systems research: issues, methods and practical guidelines (pp. 6-13). Oxford, UK: Blackwell Scientific Publications.

Marton, F. (1981) Phenomenography - describing conceptions of the world around us. Instructional Science, 10, 177-200.

Marton, F. (1986). Phenomenography - a research approach to investigating different aspects of reality. Journal of Thought, 21, 28-94.

Marton, F. (1998). Towards a theory of quality in higher education. In B.Dart \& G. Boulton-Lewis (Eds.), Teaching and learning in higher education (pp. 177-200). Camberwell, Vic., Australia: Australian Council for Educational Research.

Marton, F. \& Booth, S. (1996). The learner's experience of learning. In D.R. Olson \& N. Torrance (Eds.), The handbook of education and human development: New models of learning, teaching and schooling (pp.534-564). Oxford: Blackwell.

Marton, F. \& Booth, S. (1997). Learning and awareness. Mahwah, NJ: Erlbaum.

Mumford, E. (1996). Systems design: Ethical tools for ethical change. Chippenham, UK: MacMillan Press.

Sahraoui, S. (1998). Is information systems education value neutral? Journal of Computer Information Systems, 38 (3), 105-109.

Sandberg, J. (1994). Human competence at work: An interpretative approach. Göteborg: BAS.

Sandberg, J. (1997). Are phenomenographic results reliable? Higher Education Research and Development, 16 (2), 203-212.

Wand, Y. \& Weber, R. (1995). On the deep structure of information systems. Information Systems Journal, 5, 203-223.
Weber, R. (1996). A neglected aspect of the information systems curriculum: What is an information system? In D.Arnott, K. Dampney, \& A. Scollary, (Eds.). The Australian Debate on Information Systems Curriculum. Proceedings of the Australian Information Systems Curriculum Working Conference (pp.7175). Melbourne: Monash University, Department of Information Systems.

Winter, M.C., Brown, D.H., \& Checkland, P.B. (1995). A role for soft systems methodology in information systems development. European Journal of Information Systems, 4, 130-142.

\section{Acknowledgements}

The study reported here was part of a larger study which looked at students' experiences of learning about information system. In this study students approaches to learning about IS were also investigated and the relationship between approach to learning about IS and level of understanding of the concept of an IS. The larger study was funded by various research and travel grants from $\mathrm{La}$ Trobe University, Bendigo, Australia.

\section{Biography}

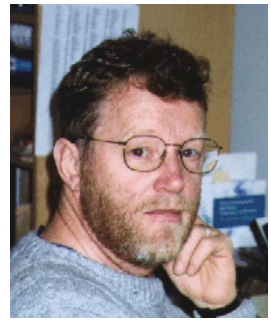

Chris Cope is a lecturer in the Department of Information Technology at La Trobe University, Bendigo, Australia. He has been teaching about IS to undergraduates and postgraduates for 16 years. His research interests are based around improving teaching about IS. To this end he has researched students' perceptions of their experiences of learning about information systems. This research has led to the implementation of changes to curriculum content and teaching approach. The changes are then evaluated in a structured way as a further research process. The research has been published in various conference proceedings, journal articles and book chapters. 